\title{
Suppression of Bacterial Spot of Tomato with Foliar Sprays of Compost Extracts Under Greenhouse and Field Conditions
}

\author{
Jaber H. Al-Dahmani, Pervaiz A. Abbasi, Sally A. Miller, and Harry A. J. Hoitink, Department of Plant Pathol- \\ ogy, The Ohio State University, Ohio Agricultural Research and Development Center, Wooster 44691
}

\begin{abstract}
Al-Dahmani, J. H., Abbasi, P. A., Miller, S. A., and Hoitink, H. A. J. 2003. Suppression of bacterial spot of tomato with foliar sprays of compost extracts under greenhouse and field conditions. Plant Dis. 87:913-919.

The efficacy of foliar sprays with compost water extracts (compost extracts) in reducing the severity of bacterial spot of tomato caused by Xanthomonas vesicatoria was investigated. Extracts prepared from composted cow manure, composted pine bark, an organic farm compost, or composted yard waste, applied as foliar sprays on tomato transplants, resulted in a moderate but statistically significant reduction in the severity of bacterial spot. The population of $X$. vesicatoria in infected leaves was reduced significantly by extracts prepared from composted cow manure. Efficacy of the water extracts was not affected by oxygen concentrations in the suspension during extraction, compost maturity, or sterilization by filtration or autoclaving. The degree of control provided by foliar sprays with the most effective compost extracts did not differ from that obtained with the plant activator acibenzolar- $S$-methyl. In the field in two growing seasons, foliar sprays with compost water extracts did not reduce the severity of foliar diseases, including bacterial spot. During the 1997 season, when the severity of bacterial spot in the field was high, foliar sprays with compost water extracts significantly reduced the incidence of bacterial spot on tomato fruit. Amending plot soil with several rates of composted yard waste did not lead to additional control of fruit disease over those only sprayed with extracts. Foliar sprays with a mixture of chlorothalonil and copper hydroxide or with acibenzolar- $S$-methyl reduced the severity of bacterial spot as well as incidence of spot on fruit.
\end{abstract}

Additional keywords: benzothiadiazole, biological control, chlorothalonil, compost-induced systemic resistance, compost tea

Water extracts prepared from composted organic matter have been used by farmers for centuries for their perceived beneficial effects on plant health (35). During the past two decades, numerous reports have shown that various types of such extracts applied as foliar sprays to plants can reduce the severity of several foliar diseases, including apple scab, powdery mildew, and gray mold $(2,11,13,23,27,33,35,36)$. Most extracts are prepared from manure-based composts (35), although extracts from other types of composts have also been effective against foliar disease (36). Compost extracts typically are prepared by mixing mature compost with tap water in

Corresponding author: Harry A. J. Hoitink E-mail: hoitink.1@osu.edu

Current address of J. H. Al-Dahmani: Department of Arid Land Agriculture, College of Food Systems, UAE University, P.O. Box 17555, Al-Ain, United Arab Emirates.

Current address of P. A. Abbasi: Agriculture and Agri-Food Canada, SCPFRC, 1391 Sandford Street, London, Ontario, N5V 4T3 Canada.

Accepted for publication 18 March 2003.

Publication no. D-2003-0528-02R

(c) 2003 The American Phytopathological Society an open container in ratios of $1: 5$ to $1: 10$ (vol/vol). The mixture is stirred and then steeped at ambient temperatures for several days to more than a week. The extract is filtered through cheesecloth or similar material and applied as a foliar spray or soil drench (35). Alternatively, extracts may be produced aerobically by bubbling air through the slurry during a 24-h extraction process (6). The efficacy of such 24-h extracts has not been confirmed to our knowledge.

Efficacy of compost extracts may vary considerably. This may in part be due to differences in procedures used for preparation of the extracts, the source, composition, quality, and maturity of the compost (35), length of storage, and possibly other factors. In addition, different groups of pathogens may respond differently to components of the compost extracts (35). Finally, compost extracts have been shown to induce natural plant defenses against pathogens. Zhang et al. (37) demonstrated that compost steepages applied to the foliage of Arabidopsis plants stimulated $\beta$-1,3-glucanase activity. Topical sprays with salicylic acid had the same effect, which led them to conclude that the compost water extract induced systemic resistance, possibly via the same mechanism.
Bacterial spot of tomato, caused by Xanthomonas vesicatoria, is a serious problem of processing and fresh market tomatoes in non-arid growing regions $(14,32)$. The disease may be seedborne, with secondary dispersal primarily through splashing rain and irrigation water. Once the disease is established in a crop, currently available management strategies are only partially effective under environmental conditions favorable for disease development and spread. Traditional management has been through multiple foliar applications of fixed copper bactericides, usually tankmixed with an ethylene-bis-dithiocarbamate fungicide such as mancozeb (10). Recently, the plant activator acibenzolar- $S$ methyl (Actigard; Syngenta Crop Protection, Greensboro, NC), which induces systemic acquired resistance (SAR) in plants $(15,24)$, has been shown to reduce bacterial spot incidence and severity $(26,31)$. Composts may induce systemic resistance in plants $(28,37)$, and composted yard waste applied to soil prior to planting also reduces bacterial spot incidence on tomato fruit, although foliar disease is not reduced (1). The objectives of this research were to determine (i) the efficacy of compost extracts against bacterial spot of tomato under greenhouse and field conditions, and (ii) interactions in control of this disease under field conditions between compost extracts applied to the foliage of tomato plants and composts incorporated into soil. An intrinsic component of these objectives was a reexamination of factors affecting efficacy of compost steepages.

\section{MATERIALS AND METHODS}

Production of seedlings. Tomato seeds cv. Ohio 7814 (Sunseeds Genetics, Inc., Hollister, CA; $91 \%$ germination) were sown in 288-cell flats containing a dark sphagnum peat/perlite mix that is low in microbial carrying capacity, naturally conducive to Pythium damping-off (4), and a noninducer of systemic resistance in plants (37). The mix was prepared by blending sphagnum peat, $\mathrm{H}_{4}$ on the von Post decomposition scale (30), received from Premier Peat Moss Ltd., Quebec, Canada, with coarse horticultural grade perlite, $1.1 \mathrm{~g}$ of superphosphate, $1.1 \mathrm{~g}$ of $\mathrm{KNO}_{3}, 1.1 \mathrm{~g}$ of gypsum, and a 3:2 ratio of dolomitic lime and calcium carbonate ( $<100$ mesh) per liter of mix to adjust the $\mathrm{pH}$ within the range of 5.3 to 5.5 . Seeded flats were maintained under natural light in a green- 
house at 22 to $24^{\circ} \mathrm{C}$. Two-week-old seedlings were transplanted into 400-ml, 10$\mathrm{cm}$-tall pots (one seedling per pot, five pots per treatment), fertilized with slow-release fertilizer (3.0 g of Osmocote 17-6-12 plus trace elements per pot; Scotts-Sierra Horticultural Products Co., Marysville, $\mathrm{OH}$ ), and maintained in the greenhouse for an additional 2 weeks.

Bacterial spot bioassay. Plants were incubated for $24 \mathrm{~h}$ in a mist chamber $\left(24^{\circ} \mathrm{C}\right.$, continuous illumination $\left[225 \mu \mathrm{E} / \mathrm{m}^{2} / \mathrm{s}\right]$, relative humidity $>95 \%$ ) before treatment application. Foliage of 4-week-old tomato plants was sprayed so as to wet leaves with compost water extracts, acibenzolar- $S$ methyl (Actigard 50WG, $35 \mathrm{mg}$ a.i./liter, Syngenta) as a positive SAR control $(15,24,26,31)$, or sterilized water. After 24 $\mathrm{h}$, the foliage of plants was sprayed to runoff with a cell suspension of $X$. vesicatoria strain $794 \mathrm{a}$ originally isolated from field tomatoes. Inoculum of the pathogen was produced on yeast dextrose carbonate (YDC) agar medium (25) in 20-ml petri dishes incubated at $28^{\circ} \mathrm{C}$ for $48 \mathrm{~h}$. Bacterial cells were washed from the plates and suspended in autoclaved tap water. The suspension was adjusted to a concentration of approximately $10^{8} \mathrm{CFU} / \mathrm{ml}$. Control plants were sprayed with water. Plants were maintained under conditions described above for $36 \mathrm{~h}$ postinoculation and then returned to the greenhouse and arranged in a completely randomized design. Seven to 10 days postinoculation, the severity of bacterial spot was determined based on a disease severity rating scale in which $1=$ symptomless, $2=$ one to five lesions per leaflet, $3=$ many lesions and some coalesced lesions, $4=$ coalesced lesions and some necrotic leaflets, and $5=$ dead leaflets.

The population of $X$. vesicatoria in tomato leaves at the time plants were rated for disease severity was determined by harvesting all leaves from three randomly selected plants per treatment. Leaflets showing symptoms of bacterial spot were harvested, weighed, and macerated with a ball bearing tissue grinder (Bioreba AG, Basel, Switzerland) in a polyethylene bag (Agdia Inc., Elkhorn, IN) utilizing an equal weight of sterilized phosphate buffer $(7 \mathrm{~g}$ of $\mathrm{K}_{2} \mathrm{HPO}_{4}$ and $3 \mathrm{~g}$ of $\mathrm{KH}_{2} \mathrm{PO}_{4}$ per liter of distilled water, $\mathrm{pH} 7.2$ to 7.4 ). Serial 10fold dilutions were then plated onto a semiselective medium for Xanthomonas spp. (CKTM; 34). After 4 days of incubation at $28^{\circ} \mathrm{C}$, colonies resembling $X$. vesicatoria were counted, and the population was then expressed as colony forming units (CFU) per gram fresh weight of tissue.

Preparation of compost water extracts. In preliminary experiments, several types of mature composts were used to determine the impact of the raw materials from which composts are prepared on extract efficacy. The composts used were: (i) an 8-month-old sawdust-bedded composted cow manure prepared in windrows according to Chen et al. (8); (ii) a 3-month-old composted pine bark (Earthgro Inc., Glastonbury, CT) prepared according to Hoitink et al. (19); (iii) a 5-month-old organic farm compost prepared from cow manure, yard wastes, and a small amount of topsoil (5\%, vol/vol; Fresh Aire Farms, Union City, $\mathrm{OH})$; and (iv) an 8-month-old composted yard waste (Kurtz Bros. Inc., Columbus, $\mathrm{OH})$ prepared according to Grebus et al. (16). The extracts were prepared according to the steepage procedure of Weltzien (35). Each cured compost was suspended in tap water $(1: 5, \mathrm{vol} / \mathrm{vol})$ in a loosely covered 20-liter plastic container (Rubbermaid, Inc., Wooster, $\mathrm{OH}$ ). The suspension was incubated for 7 days at 20 to $22^{\circ} \mathrm{C}$ and stirred twice during this time. Extracts were then filtered through cheesecloth to remove large particles and to avoid clogging of sprayer nozzles.

Effects of compost maturity, aeration, compost-to-water ratio, and filtration on compost extract potency. Sawdustbedded cow manure was composted in windrows that were turned frequently over a 7-week period as described previously (8). Thereafter, the compost was cured in $20 \mathrm{~m}^{3}$ piles. To determine the effect of compost maturity on extract efficacy, samples of compost (30 liters) were collected from curing piles after 5, 10, and 16 months by pooling 2.5-liter subsamples retrieved from 12 locations in each pile. This pooled sample was then blended in a polyethylene bag, and a steeped extract was prepared as described above and then stored at $-15^{\circ} \mathrm{C}$ until a bioassay was performed.

The effect of aeration on compost extract efficacy was evaluated using sawdustbedded composted cow manure. Extracts were prepared using (i) the steepage method as described above, (ii) the steepage method with aeration ("aerobic extract"), and (iii) anaerobically. For the aerobic extract, air was forced through the compost/water slurry from four air hoses located in each steepage container up through the suspension during the 7-day period. The container was covered with a lid to minimize evaporation of water. Anaerobic extracts were produced in an anaerobic jar (nonvented model of GasPak 150 System, Becton Dickinson \& Co., Franklin Lakes, NJ) equipped with $\mathrm{O}_{2}$ absorber envelopes and $\mathrm{CO}_{2}$ indicator strips. Within a few minutes after closure of the jar, the color of the $\mathrm{CO}_{2}$ indicator changed from blue to white, indicating the establishment of anaerobic conditions. All extracts were filtered though cheesecloth as described above and tested for ability to reduce bacterial spot incidence on tomato transplants.

The effect of compost to water ratio on efficacy against bacterial spot was determined by blending 8-month-cured composted cow manure with water at volumet- ric ratios of $1: 1,1: 3$, and $1: 5$. The slurries were steeped, filtered, and then tested for efficacy on tomato plants.

The effects of filter and heat sterilization on compost extract efficacy were determined using steeped compost extracts prepared from 8-month-cured composted cow manure. The extracts were centrifuged $(7,500 \times g$ for $10 \mathrm{~min})$ to remove large compost particles. The partially cleared extracts were then filtered through Whatman no. 1 filter paper and filtersterilized using a $115-\mathrm{ml}$ disposable vacuum filtration unit (pore sizes 0.45 and 0.2 $\mu \mathrm{M}$ ) equipped with a surfactant-free cellulose acetate (SFCA) membrane (Nalge Co., Rochester, NY). These units are designed to minimize protein binding. Sterility of the extracts was confirmed by spreading $0.1 \mathrm{ml}$ of each extract on 0.1 strength Difco trypticase soy agar (TSA) medium. Plates were incubated at $28^{\circ} \mathrm{C}$ for $48 \mathrm{~h}$. Heat treatment of steeped extracts was performed by autoclaving them at $121^{\circ} \mathrm{C}$ for $30 \mathrm{~min}$. Filtered and autoclaved extracts were tested for efficacy against bacterial spot using the tomato bioassay described above.

Field evaluation of compost extracts. Field trials were conducted in 1997 and 1998 at OSU/OARDC, Wooster, OH, on experimental plots that had not been treated with organic amendments for 30 years. The field soil was a silty loam type. The experiment in both seasons was a split-split plot design with four replicates per treatment.

Tomato transplants of the cultivar Peto 696 (Petoseed Co., Inc., Saticoy, CA) were produced in the greenhouse according to standard procedures (29) in a composted pine bark-amended plug mix received from Earthgro Inc., Glastonbury, CT, or a standard sphagnum peat mix used by the tomato industry (BACCTO High Porosity Professional Planting Mix, Michigan Peat Co., Houston, TX). In preliminary tests, it was determined that this compost-amended transplant mix did not affect the severity of bacterial spot compared with that of seedlings in the peat mix. Tomato seeds were mechanically sown $1 \mathrm{~cm}$ deep in 288-cell plug flats maintained in the greenhouse at 20 to $26^{\circ} \mathrm{C}$ with a natural photoperiod. They were irrigated daily and fertilized weekly with Peter's standard fertilizer (2020-20 [N-P-K], 454 g per 378 liters) (W. R. Grace and Co., Cambridge, MA) and then transplanted into the field.

Composted yard waste amendment was the main plot, transplant mix was the subplot, and spray treatments were subsubplots. The plot size for each compost treatment was $13.7 \times 5.5 \mathrm{~m}$, and each individual experimental unit (a compost-mixspray treatment combination within a replication) was $5.5 \times 0.5 \mathrm{~m}$. Three compost treatments were included in the 1997 field trial. Composted yard wastes, prepared at Kurtz Bros. Inc., Independence, OH, ac- 
cording to Grebus et al. (16), was applied in April 1997 to the main plots at a low rate (24.5 t dry wt./ha) and a high rate (49 $\mathrm{t}$ dry wt./ha). The compost was tilled into the soil to a depth of 5 to $7.5 \mathrm{~cm}$. Plots not amended with compost served as a control. In April 1998, the same source of composted yard waste was applied at rates of 0 , 36.8, and $73.6 \mathrm{t}$ dry wt./ha. The stability of the composts exceeded $0.5 \mathrm{~g} \mathrm{O}_{2}$ uptake per $\mathrm{kg}$ dry wt. volatile solids/h, which is considered below the threshold of phytotoxicity (22). To maintain approximately equivalent fertility conditions among treatments, chemical analyses of the composts and the amended soils were performed. The quantity of available N-P-K provided by each compost batch and rate was determined, based on analysis and expected nutrient release rates. Control plots were amended with potassium nitrate (13.75-0-44.5 [N-P-K]) and treble super phosphate $(0-46-0[\mathrm{~N}-\mathrm{P}-\mathrm{K}])$ to increase the concentrations of $\mathrm{N}, \mathrm{P}$, and $\mathrm{K}$ on all plots to 86,58 , and $275 \mathrm{~kg} / \mathrm{ha}$, respectively, to meet the recommended fertility levels for processing tomatoes (29). Raised planting beds were prepared that were spaced $1.5 \mathrm{~m}$ between centers. Finally, in the first week of June each year, tomato seedlings were transplanted into single rows at a $30-\mathrm{cm}$ distance within a row. A total of 15 seedlings were planted per replicate per treatment. Starter fertilizer (Peter's 20-20-20 [N-P-K], 454 g per 378 liters) was applied to seedlings immediately after transplanting. Irrigation water was applied by sprinkler irrigation as needed thereafter.

The compost from which extracts for application in the field were prepared in 1997 and 1998 was a sawdust-bedded cow manure amended with a layer of poultry manure (3:1, vol/vol, respectively) that was cured for at least 7 months. Compost steepages were prepared by blending compost with water (1:5, vol/vol, respectively) in 20-gallon plastic containers incubated for 7 days at 20 to $24^{\circ} \mathrm{C}$ and stirred twice during this period. The extract was filtered through cheesecloth as described above to remove large particles. The compost water extract was used immediately thereafter. The compost extract was also tested in the tomato growth chamber bioassay as described above to ensure efficacy against bacterial spot. All applications were made early in the morning or late in the evening. Compost water extracts were applied weekly or biweekly as sprays to the foliage of tomato plants utilizing a standard backpack sprayer. The SAR inducer acibenzolar-S-methyl (35 g a.i./ha) and the fungicide chlorothalonil (Bravo Ultrex, 82.5 WDG, Syngenta Crop Production, Greensboro, NC; $2 \mathrm{~kg} / \mathrm{ha}$ ) alone in 1997 and in combination with copper hydroxide (Kocide $101 ; 2 \mathrm{~kg} / \mathrm{ha}$ ) in 1998 were applied at 7- to 10-day intervals. A total of 12 applications of these treatments were made each year. All foliar spray treatments were ap- plied from 3 weeks after transplanting until 2 weeks before harvest.

Plots were inoculated with a mixture of five strains of $X$. vesicatoria race T2 (sensitive to copper and pathogenic to tomato) by spraying plants to runoff with freshly prepared inoculum $\left(10^{8} \mathrm{CFU} / \mathrm{ml}\right)$ of the pathogen using a backpack sprayer. Free moisture and high humidity conditions were maintained on the foliage for $4 \mathrm{~h}(24$ $\mathrm{h}$ before and $48 \mathrm{~h}$ after inoculation) by sprinkler irrigation. The severity of foliar diseases, including bacterial spot, early blight (Alternaria solani (Ellis \& G. Martin) L.R. Jones \& Grout), and Septoria leaf blight (Septoria lycopersici Speg.), was assessed visually utilizing a HorsfallBarratt rating scale (21). No attempt was made to evaluate symptoms of these three diseases separately. Visual assessments were made three times during $\mathrm{Au}-$ gust/September at 12-day intervals in 1997 and at 10-day intervals in 1998. Midpoints of the Horsfall-Barratt rating scale were used to calculate area under the disease progress curves (AUDPC). Tomato fruits were harvested from the middle five plants of each replicate for each treatment to determine the incidence of bacterial spot, anthracnose, and other diseases on fruit.

Statistical analyses. Greenhouse data were analyzed using MINITAB statistical software version 11.11 (Minitab Inc., State College, PA). Analysis of variance (ANOVA) was performed, and if $P$ values indicated a significant difference $(P \leq$ $0.05)$, means were separated by Fisher's protected least significant difference (LSD) test. The data on compost maturity and compost concentration were analyzed using the general linear model (GLM) procedure of SAS statistical software version 8.0 (SAS Institute Inc., Cary, NC), and means were separated with least squares estimates of marginal means (LS MEANS statement).

Field data were analyzed using SAS statistical software, ANOVA was performed using the GLM procedure of SAS, and means were separated with least squares estimates of marginal means (LS MEANS statement).

Table 1. Efficacy of compost water extracts (CWE) from four different types of composts against bacterial spot on tomato transplants

\begin{tabular}{lccc}
\hline & \multicolumn{3}{c}{ Bacterial spot severity $^{\mathbf{y}}$} \\
\cline { 2 - 4 } Treatments $^{\mathbf{x}}$ & Test $\mathbf{1}$ & Test $\mathbf{2}$ & Mean \\
\hline Tap water & $3.2 \mathrm{a}^{\mathrm{z}}$ & $3.4 \mathrm{a}$ & $3.3 \mathrm{a}$ \\
CWE-composted cow manure & $1.8 \mathrm{~b}$ & $1.6 \mathrm{c}$ & $1.7 \mathrm{bc}$ \\
CWE-composted pine bark & $1.8 \mathrm{~b}$ & $1.6 \mathrm{c}$ & $1.7 \mathrm{bc}$ \\
CWE-organic farm compost & $2.0 \mathrm{~b}$ & $2.6 \mathrm{ab}$ & $2.3 \mathrm{~b}$ \\
CWE-composted yard waste & $1.6 \mathrm{~b}$ & $2.0 \mathrm{bc}$ & $1.8 \mathrm{bc}$ \\
Acibenzolar- $S$-methyl & $1.4 \mathrm{~b}$ & $1.4 \mathrm{c}$ & $1.4 \mathrm{c}$ \\
\hline
\end{tabular}

${ }_{\mathrm{x}}$ Treatments were sprayed onto leaves of 4-week-old tomato transplants $24 \mathrm{~h}$ prior to inoculation with Xanthomonas vesicatoria $\left(10^{8} \mathrm{CFU}^{-1} \mathrm{ml}\right)$. Acibenzolar- $S$-methyl applied at $35 \mathrm{mg}$ a.i. liter ${ }^{-1}$.

${ }^{\mathrm{y}}$ Disease severity based on five replicates per treatment and a 1 to 5 rating scale in which $1=$ symptomless and $5=$ dead leaflets determined 7 to 10 days after inoculation.

${ }^{\mathrm{z}}$ Means followed by the same letter in each column do not differ significantly according to Fisher's least significant difference at $P \leq 0.05$.

\section{ESULTS}

cacy. For the first bioassay, efficacy of the steeped compost extracts prepared from the four types of composts was comparable to that of acibenzolar-S-methyl (Table 1). In the second bioassay, steepages prepared pine bark also were as effective as acibenzolar-S-methyl, but the organic farm compost was less effective. The extracts from the four different composts also were commercial batch of transplant mix with properties similar to those described above these tests, the mean severity of bacterial spot on transplants sprayed with the steepage prepared from the composted cow manure was consistently as low as the rity on plants treated with acibenzolarwas used for preparation of extracts for al other greenhouse experiments.

Steeped compost water extracts prepared from three different batches of composted populations of $X$. vesicatoria in infected tomato leaves compared with the water control (Table 2). Two of the extracts reduced the population by almost one order magnitude. All three steeped extracts bacterial spot. The $\mathrm{pH}$ of the steeped extracts from the three different batches of composts ranged from 7.3 to 8.3. Their conductivity ranged from 0.8 to 4.0 stunting of growth were not observed on any of the treated plants.

Effect of compost maturity, compostto-water ratio, aeration, and filtercacy of compost water extracts. In each of two tests, steeped extracts prepared from or 16 months significantly reduced the severity of bacterial spot. Compost maturity did not affect efficacy of the steepages against bacterial spot in the tomato seedling bioassay (Table 3). All compost extracts were as effective as sprays with aci- 
benzolar-S-methyl for the control of bacterial spot.

Steeped compost extracts prepared at volumetric ratios of $1: 1,1: 3$, and $1: 5$ (compost:water, vol/vol) significantly reduced the severity of bacterial spot compared with the water control. There was no significant effect due to compost concentration (Table 4). None caused phytotoxic effects on the foliage. In each of two experiments, steeped, aerobically or anaerobically produced extracts were consistently effective in reducing the severity of bacterial spot compared with the water control (Table 5). The extracts did not differ from one another in efficacy.

Steeped extracts that were sterilized by filtration $(0.2$ or $0.45 \mu \mathrm{M}$ pore diameter) or autoclaving significantly reduced the severity of bacterial spot compared with the water control in several experiments. Data for two such tests are presented in Table 6 . Overall trends for both tests were similar even though the disease pressure in test 1 was much lower than in test 2 .

Effects of compost extracts on foliar disease severity in field tomatoes. Bacterial spot, early blight, and Septoria leaf spot were observed on field tomatoes during the 1997 and 1998 growing seasons. Bacterial spot disease pressure was high in 1997 and very low in 1998. In 1998, overall disease severity was high, but most was attributable to early blight and Septoria leaf spot. Severity of all three diseases combined, based on AUDPC values, was higher on plots amended with the low or the high rates of composted yard waste than on nonamended control plots, regardless of foliar treatments (Table 7). In both years, the severity of these foliar diseases on plots sprayed with compost water extracts at 1- or 2-week intervals, or with chlorothalonil alone, irrespective of compost amendment, did not differ from that on control plots sprayed with water (Table 7). In contrast, foliar sprays with acibenzolar- $S$-methyl significantly reduced the severity of the foliar diseases on the compost-amended plots in both years. On nonamended control plots, acibenzolar- $S$ methyl was also effective in 1997 when bacterial spot pressure was high. Foliar sprays with the mixture of chlorothalonil and copper hydroxide applied in 1998 significantly reduced disease severity on compost-amended as well as nonamended control plots.

Effects of extracts on bacterial spot on tomato fruit in the field. Foliar sprays with compost extracts significantly reduced the incidence of bacterial spot on fruit harvested from control plots (not amended with compost) in 1997 (Table 8). The incidence of bacterial spot on fruit was also significantly lower on plots amended

Table 2. Suppression of bacterial spot and of populations of Xanthomonas vesicatoria in tomato transplants sprayed with compost water extracts (CWE)

\begin{tabular}{|c|c|c|}
\hline Treatments $^{\mathrm{w}}$ & $\begin{array}{l}\text { Bacterial spot }{ }^{\mathrm{x}} \\
\text { severity }\end{array}$ & $\begin{array}{l}\text { Bacterial population }{ }^{y} \\
\left(\log _{10} \text { CFU/g fresh wt.) }\right.\end{array}$ \\
\hline Tap water & $3.4 \mathrm{a}^{\mathrm{z}}$ & $7.2 \mathrm{a}$ \\
\hline CWE-composted cow manure batch 2 & $2.0 \mathrm{c}$ & $6.4 \mathrm{~b}$ \\
\hline CWE-composted cow manure batch 6 & $2.8 \mathrm{~b}$ & $6.7 \mathrm{~b}$ \\
\hline CWE-composted cow manure batch 7 & $2.2 \mathrm{c}$ & $6.4 \mathrm{~b}$ \\
\hline
\end{tabular}

${ }^{\mathrm{w}} \mathrm{CWE}$ prepared from composted cow manure were sprayed onto the foliage of 4-week-old tomato

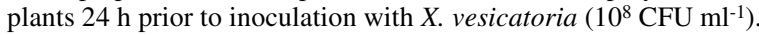

${ }^{\mathrm{x}}$ Disease severity based on five replicates per treatment and a 1 to 5 rating scale in which $1=$ symptomless and $5=$ dead leaflets determined 7 to 10 days after inoculation.

${ }^{y}$ Populations of $X$. vesicatoria (CFU g ${ }^{-1}$ fresh wt.) from leaves of three randomly selected plants were determined by dilution plating onto CKTM medium. CFU data were then transformed to $\log$ $\mathrm{CFU} \mathrm{g^{-1 }}$ fresh wt. of leaf. Each value is the mean of three plates per replicate and three replicates per treatment. Xanthomonas was not detected on noninoculated leaves.

${ }^{\mathrm{z}}$ Means followed by the same letter in each column do not differ significantly according to Fisher's least significant difference at $P \leq 0.05$.

Table 3. Effects of compost maturity on the efficacy of compost water extracts (CWE) in the control of bacterial spot of tomato

\begin{tabular}{lll}
\hline & \multicolumn{2}{c}{ Bacterial spot severity $^{\mathbf{y}}$} \\
\cline { 2 - 3 } Treatments $^{\mathbf{x}}$ & Test 1 & Test 2 \\
\hline Tap water & $3.4 \mathrm{a}^{\mathrm{z}}$ & $3.2 \mathrm{a}$ \\
CWE (3-month cured compost) & $1.4 \mathrm{~b}$ & $2.4 \mathrm{~b}$ \\
CWE (5-month cured compost) & $2.2 \mathrm{~b}$ & $2.6 \mathrm{~b}$ \\
CWE (10-month cured compost) & $1.8 \mathrm{~b}$ & $2.2 \mathrm{~b}$ \\
CWE (16-month cured compost) & $2.2 \mathrm{~b}$ & $1.9 \mathrm{~b}$ \\
Acibenzolar-S-methyl & $2.2 \mathrm{~b}$ & $2.4 \mathrm{~b}$ \\
\hline
\end{tabular}

$\bar{x}$ All treatments were sprayed onto the foliage of 4-week-old seedlings $24 \mathrm{~h}$ prior to inoculation with Xanthomonas vesicatoria $\left(10^{8} \mathrm{CFU} \mathrm{ml}^{-1}\right)$. Acibenzolar-S-methyl applied at $35 \mathrm{mg}$ a.i. liter ${ }^{-1}$.

${ }^{y}$ Disease severity based on five replicates per treatment and a 1 to 5 rating scale in which $1=$ symptomless and $5=$ dead leaflets.

${ }^{\mathrm{z}}$ Means followed by the same letter in each column do not differ significantly according to least squares means option of the general linear models procedure of SAS at $P \leq 0.05$. with composted yard wastes than on nonamended control plots. Foliar applications of compost water extracts made at weekly intervals were not more effective than those made at 2-week intervals. The extracts did not affect the incidence of bacterial spot on fruit in plots amended with either low or high loading rates of compost, where the severity of the disease already was low (Table 8). Chlorothalonil applied alone did not reduce the incidence of disease on fruit compared with the water control. The effect of acibenzolar- $S$-methyl on the incidence of bacterial spot on fruit was similar to that of the compost water extracts.

In 1998, the incidence of bacterial spot on fruit was much lower than in 1997 (Table 8). Neither compost extracts nor compost amendments reduced bacterial spot incidence on fruit significantly. However, treatment with a mixture of chlorothalonil and copper hydroxide significantly reduced bacterial spot on fruit for all compost amendment treatments. Acibenzolar- $S$ methyl did not significantly reduce bacterial spot on fruit for any of the compost amendment treatments, but the effect was significant when averaged across all compost treatments (main effect).

Effect of compost water extracts on yield. Foliar sprays of compost water extracts did not increase yield of healthy fruit compared with the water control (Table 9). Total fruit yields were much higher in 1997 than in 1998. Chlorothalonil and copper sulfate was the only treatment that increased the total fruit yield compared with the water control. However, yields of healthy (marketable) fruit were significantly higher in plots treated with chlorothalonil alone (1997), chlorothalonil and copper sulfate (1998), and acibenzolar$S$-methyl (1998) than the water control. Both chlorothalonil combined with copper sulfate and acibenzolar- $S$-methyl significantly reduced the proportion of ripe fruit compared with plants treated with water only.

Table 4. Effects of compost solids-to-water volumetric ratio on the efficacy of steeped compost water extracts in the control of bacterial spot on tomato transplants

\begin{tabular}{lc}
\hline Treatments $^{\mathbf{y}}$ & $\begin{array}{c}\text { Mean bacterial } \\
\text { spot severity }^{\mathbf{z}}\end{array}$ \\
\hline Tap water & $3.3 \mathrm{a}$ \\
Compost water extract $(1: 5)$ & $2.0 \mathrm{~b}$ \\
Compost water extract $(1: 3)$ & $1.9 \mathrm{~b}$ \\
Compost water extract $(1: 1)$ & $1.8 \mathrm{~b}$ \\
\hline${ }^{\mathrm{y}}$ All treatments were sprayed onto the foliage \\
of 4-week-old seedlings $24 \mathrm{~h}$ prior to inocula- \\
tion with Xanthomonas vesicatoria $\left(10^{8} \mathrm{CFU}\right.$ \\
$\left.\mathrm{ml}^{-1}\right)$. \\
${ }^{\mathrm{z}}$ Disease severity data are an average of two \\
experiments (n = 10) based on a 1 to 5 rating \\
scale in which 1 = symptomless and $5=$ dead \\
leaflets. Means followed by the same letter do \\
not differ significantly according to least \\
squares means option of the general linear \\
models procedure of SAS at $P \leq 0.05$.
\end{tabular}




\section{DISCUSSION}

Efficacy of the compost extracts against bacterial spot ranged from effective on tomato seedlings in greenhouse bioassays, to marginally effective on fruit in the field under high disease pressure, to ineffective in the field against the foliar phase of the disease. Under some conditions, the extracts were as effective as acibenzolar- $S$ methyl. In all but one instance, control with the steeped extracts was as good as that observed with acibenzolar- $S$-methyl. However, compost extracts were not as effective as acibenzolar-S-methyl in reducing the severity of foliar diseases when bacterial spot pressure was high. Control obtained with the fungicide mixture of chlorothalonil and copper hydroxide was most effective across all compost soil amendments in 1998 field trial. Copper hydroxide was not included in 1997 field trial.

Lack of efficacy of compost extracts against foliar disease in the field in 1997 under high disease pressure and a significant reduction of bacterial spot on fruit with weekly as well as biweekly sprays on control plots not amended with compost seems peculiar. The effect on fruit was

Table 5. Effects of aeration during the preparation of compost water extracts on efficacy in the control of bacterial spot on tomato transplants

\begin{tabular}{lccc}
\hline & \multicolumn{3}{c}{ Bacterial spot severity $^{\mathbf{x}}$} \\
\cline { 2 - 4 } Treatments $^{\mathbf{w}}$ & Test $\mathbf{1}$ & Test $\mathbf{2}^{\mathrm{z}}$ & Means $^{\mathbf{y}}$ \\
\hline Tap water & $3.0 \mathrm{a}^{\mathrm{z}}$ & $3.7 \mathrm{a}$ & $3.4 \mathrm{a}$ \\
Steeped extract & $2.1 \mathrm{~b}$ & $3.1 \mathrm{~b}$ & $2.6 \mathrm{~b}$ \\
Aerobic extract & $2.1 \mathrm{~b}$ & $3.1 \mathrm{~b}$ & $2.6 \mathrm{~b}$ \\
Anaerobic extract & $2.2 \mathrm{~b}$ & $2.9 \mathrm{~b}$ & $2.6 \mathrm{~b}$ \\
\hline
\end{tabular}

${ }^{w}$ All treatments were sprayed onto the foliage of 4 -week-old seedlings $24 \mathrm{~h}$ prior to inoculation with X. vesicatoria $\left(10^{8} \mathrm{CFU} \mathrm{ml}{ }^{-1}\right)$.

${ }^{\mathrm{x}}$ Disease severity based on five replicates per treatment and a 1 to 5 rating scale in which $1=$ symptomless and $5=$ dead leaflets.

y Means of both tests based on two-way ANOVA.

${ }^{\mathrm{z}}$ Means followed by the same letter in each column do not differ significantly according to Fisher's least significant difference at $P \leq 0.05$.

Table 6. Effects of filtration or autoclaving on the efficacy of compost water extracts in the control of bacterial spot on tomato transplants

\begin{tabular}{lccc}
\hline & \multicolumn{3}{c}{ Bacterial spot severity $^{\mathbf{x}}$} \\
\cline { 2 - 4 } Treatments $^{\mathbf{w}}$ & Test $\mathbf{1}$ & Test 2 & Means $^{\mathbf{y}}$ \\
\hline Tap water & $2.7 \mathrm{a}^{\mathrm{z}}$ & $3.7 \mathrm{a}$ & $3.2 \mathrm{a}$ \\
Steeped extract & $1.8 \mathrm{~b}$ & $3.1 \mathrm{~b}$ & $2.5 \mathrm{~b}$ \\
Filtered extract $(0.45 \mu \mathrm{M})$ & $1.9 \mathrm{~b}$ & $2.6 \mathrm{~b}$ & $2.3 \mathrm{~b}$ \\
Filtered extract $(0.20 \mu \mathrm{M})$ & $2.0 \mathrm{~b}$ & $2.9 \mathrm{~b}$ & $2.5 \mathrm{~b}$ \\
Autoclaved extract & $2.1 \mathrm{~b}$ & $2.5 \mathrm{~b}$ & $2.3 \mathrm{~b}$ \\
\hline
\end{tabular}

${ }^{\mathrm{w}}$ All treatments were sprayed onto the foliage of 4 -week-old seedlings $24 \mathrm{~h}$ prior to inoculation with Xanthomonas vesicatoria $\left(10^{8} \mathrm{CFU} \mathrm{\textrm {ml } ^ { - 1 }}\right)$.

${ }^{\times}$Disease severity based on five replicates per treatment and a 1 to 5 rating scale in which $1=$ symptomless and $5=$ dead leaflets.

${ }^{\mathrm{y}}$ Means of both tests based on two-way ANOVA.

${ }^{z}$ Means followed by the same letter in each column do not differ significantly according to Fisher's least significant difference at $P \leq 0.05$.

highly significant and consistent among these treatments compared with the water control. It is interesting that compost extracts did not affect the severity on fruit on the compost-amended plots. This is in agreement with the work of Zhang et al. (37), who showed that compost extracts significantly reduced the severity of bacterial speck caused by Pseudomonas syringae pv. maculicola on Arabidopsis plants grown in a sphagnum peat mix that did not induce systemic resistance in plants. The extracts did not further reduce the severity of bacterial speck on Arabidopsis plants grown in a composted pine bark mix fortified with Chryseobacterium gleum and Trichoderma hamatum 382. The latter biocontrol agent induces systemic resistance in plants, whereas $C$. gleum does not induce this effect (17). The steepage used by Zhang et al. (37) induced SAR. Possibly, systemic resistance also explains the effects of extracts and soil-incorporated composts on tomato in this work.

The extracts used in this work did not cause phytotoxicity on plants. All were prepared from highly stabilized, mature composts. Thus, phytotoxic products produced during fermentation of composts prepared from high $\mathrm{C} / \mathrm{N}$ ratio wastes or toxicity due to excessive concentrations of ammoniacal nitrogen associated with inadequately matured low $\mathrm{C} / \mathrm{N}$ ratio composts (9) did not pose problems in this work. Extracts from such inadequately matured composts may also contain high concentrations of nutrients (glucose, amino acids, etc.). This can support growth of coliforms and other human pathogens during the preparation of compost extracts and thus contamination of food with these agents (12). For a variety of reasons, therefore, compost steepages should only be prepared from highly stabilized composts even though this research shows that extracts from partially stabilized composts were effective.

The mechanism of activity of the extracts used in this work may differ from

Table 7. Effects of foliar sprays with compost water extracts (CWE) and of compost amendments on foliar disease severity (AUDPC) in field tomatoes

\begin{tabular}{|c|c|c|c|c|c|c|c|c|}
\hline \multirow[b]{3}{*}{ Spray treatments ${ }^{x}$} & \multicolumn{8}{|c|}{ Foliar disease severity (AUDPC values) } \\
\hline & \multicolumn{4}{|c|}{ Compost amendment 1997} & \multicolumn{4}{|c|}{ Compost amendment 1998} \\
\hline & None & Low & High & Main effects & None & Low & High & Main effects \\
\hline Water & $431 \mathrm{~cd}^{\mathrm{z}}$ & $997 \mathrm{~b}$ & $1,160 a b$ & $863 \mathrm{a}$ & $368 \mathrm{bcd}$ & $755 \mathrm{a}$ & $854 \mathrm{a}$ & $659 \mathrm{a}$ \\
\hline Chlorothalonil & $529 \mathrm{c}$ & $979 \mathrm{~b}$ & $970 \mathrm{~b}$ & $826 \mathrm{a}$ & & & $\ldots$ & \\
\hline $\begin{array}{l}\text { Chlorothalonil + copper } \\
\text { hydroxide }\end{array}$ & $\ldots$ & $\ldots$ & $\ldots$ & $\ldots$ & $122 \mathrm{e}$ & $174 \mathrm{e}$ & $214 \mathrm{de}$ & $170 \mathrm{c}$ \\
\hline Acibenzolar-S-methyl & $143 \mathrm{e}$ & $249 \mathrm{de}$ & $411 \mathrm{~cd}$ & $267 \mathrm{~b}$ & $278 \mathrm{cde}$ & $512 \mathrm{~b}$ & $395 \mathrm{bc}$ & $395 \mathrm{~b}$ \\
\hline CWE 1-week interval & $570 \mathrm{c}$ & $1,093 \mathrm{ab}$ & $1,280 \mathrm{a}$ & $981 \mathrm{a}$ & $381 \mathrm{bcd}$ & $767 \mathrm{a}$ & $823 \mathrm{a}$ & $657 \mathrm{a}$ \\
\hline CWE 2-week interval & $447 \mathrm{~cd}$ & $1,121 \mathrm{ab}$ & $1,047 \mathrm{ab}$ & 871 a & $281 \mathrm{cde}$ & $742 \mathrm{a}$ & 746 a & $590 \mathrm{a}$ \\
\hline Main effects & $424 \mathrm{~b}$ & $888 \mathrm{a}$ & $974 \mathrm{a}$ & $\ldots$ & $268 \mathrm{~b}$ & $590 \mathrm{a}$ & $606 \mathrm{a}$ & $\ldots$ \\
\hline
\end{tabular}

${ }^{\mathrm{x}}$ Chlorothalonil (Bravo Ultrex) alone (1997; $2 \mathrm{~kg} \mathrm{ha}^{-1}$ ) in 1997 or mixed with copper hydroxide in 1998 (Kocide 101; $2 \mathrm{~kg}{ }^{-1}$ ) or acibenzolar- $S$-methyl (35 g a.i. ha $\left.{ }^{-1}\right)$ were applied at 7- to 10-day intervals, with 12 applications in total per season. CWE were applied at weekly or biweekly intervals. Control plants were sprayed with water.

y AUDPC (area under the disease progressive curve) values were determined from midpoints of the Horsfall-Barratt scale for three foliar disease severity ratings, bacterial spot, early blight, and Septoria leaf spot made at 12-day intervals during August 1997 and at 10-day intervals during August 1998.

${ }^{\mathrm{z}}$ Means followed by the same letter in each column and row within each year excluding main effects do not differ significantly $(P \leq 0.05$, least squares means option of the general linear models procedure of SAS). 
Table 8. Effects of foliar sprays with compost water extracts (CWE) and of compost amendments on the incidence of bacterial spot on fruit in field tomatoes

\begin{tabular}{|c|c|c|c|c|c|c|c|c|}
\hline \multirow[b]{3}{*}{ Spray treatments ${ }^{x}$} & \multicolumn{8}{|c|}{ Tomato fruit affected by bacterial spot $(\%)^{y}$} \\
\hline & \multicolumn{4}{|c|}{ Compost amendment 1997} & \multicolumn{4}{|c|}{ Compost amendment 1998} \\
\hline & None & Low & High & Main effects & None & Low & High & Main effects \\
\hline Water & $21.9 \mathrm{a}^{\mathrm{z}}$ & $8.3 \mathrm{de}$ & $14.0 \mathrm{bcd}$ & $14.7 \mathrm{a}$ & $4.0 \mathrm{a}-\mathrm{d}$ & $6.0 \mathrm{ab}$ & $5.4 \mathrm{ab}$ & $5.1 \mathrm{a}$ \\
\hline Chlorothalonil & $19.3 \mathrm{ab}$ & 9.1 cde & 9.2 cde & $12.5 \mathrm{ab}$ & $\ldots$ & $\ldots$ & $\ldots$ & \\
\hline $\begin{array}{l}\text { Chlorothalonil + copper } \\
\text { hydroxide }\end{array}$ & $\ldots$ & $\cdots$ & $\cdots$ & $\ldots$ & $0.6 \mathrm{e}$ & $1.1 \mathrm{de}$ & $1.1 \mathrm{de}$ & $0.9 \mathrm{c}$ \\
\hline Acibenzolar-S-methyl & $12.9 \mathrm{cde}$ & $8.0 \mathrm{e}$ & $7.9 \mathrm{e}$ & $9.6 \mathrm{~b}$ & $2.2 \mathrm{cde}$ & $3.0 \mathrm{~b}-\mathrm{e}$ & $3.5 \mathrm{a}-\mathrm{e}$ & $2.9 \mathrm{~b}$ \\
\hline CWE 1-week interval & $12.7 \mathrm{cde}$ & 11.7 cde & 10.8 cde & $11.7 \mathrm{ab}$ & 3.7 a-e & $4.8 \mathrm{abc}$ & $5.5 \mathrm{ab}$ & $4.7 \mathrm{a}$ \\
\hline CWE 2-week interval & $14.1 \mathrm{bc}$ & 10.6 cde & $12.6 \mathrm{cde}$ & $12.4 \mathrm{ab}$ & $3.4 \mathrm{~b}-\mathrm{e}$ & $6.7 \mathrm{a}$ & $6.0 \mathrm{ab}$ & $5.4 \mathrm{a}$ \\
\hline Main effects & $16.2 \mathrm{a}$ & $9.5 \mathrm{~b}$ & $10.9 \mathrm{~b}$ & $\ldots$ & $2.8 \mathrm{a}$ & $4.3 \mathrm{a}$ & $4.3 \mathrm{a}$ & $\ldots$ \\
\hline
\end{tabular}

$\overline{\mathrm{x}}$ Twelve foliar applications of chlorothalonil (Bravo Ultrex) alone (1997; $2 \mathrm{~kg} \mathrm{ha}{ }^{-1}$ ) or mixed with copper hydroxide (Kocide 101) (1998; 2 kg/ha) or acibenzolar- $S$-methyl (35 g a.i. ha ${ }^{-1}$ ) were applied at 7- to 10-day intervals. CWE were applied at weekly or biweekly intervals. Control plants were sprayed with water.

y Percent total fruit with bacterial spot symptoms (\% of total fruit).

${ }^{\mathrm{z}}$ Means followed by the same letter in each column and row within each year excluding main effects do not differ significantly $(P \leq 0.05$, least squares means option of the general linear models procedure of SAS).

Table 9. Main effects of foliar sprays of compost water extracts (CWE) on healthy disease-free, total, and percentage of ripe fruit in field tomatoes

\begin{tabular}{|c|c|c|c|c|c|c|}
\hline \multirow[b]{2}{*}{ Spray treatments ${ }^{x}$} & \multicolumn{2}{|c|}{ Healthy fruit ( $\left.t \mathrm{ha}^{-1}\right)$} & \multicolumn{2}{|c|}{ Total fruit (t ha-1) } & \multicolumn{2}{|c|}{ Ripe fruit $(\%)^{y}$} \\
\hline & 1997 & 1998 & 1997 & 1998 & 1997 & 1998 \\
\hline Water & $53.7 \mathrm{~b}^{\mathrm{z}}$ & $30.1 \mathrm{c}$ & $75.8 \mathrm{a}$ & $37.9 \mathrm{~b}$ & $83.7 \mathrm{a}$ & $87.5 \mathrm{a}$ \\
\hline Chlorothalonil & $61.6 \mathrm{a}$ & $\ldots$ & $80.7 \mathrm{a}$ & $\ldots$ & $84.4 \mathrm{a}$ & $\ldots$ \\
\hline Chlorothalonil + copper sulfate & $\ldots$ & $46.5 \mathrm{a}$ & $\ldots$ & $48.6 \mathrm{a}$ & $\ldots$ & $67.7 \mathrm{c}$ \\
\hline Acibenzolar- $S$-methyl & $59.3 \mathrm{a}$ & $37.1 \mathrm{~b}$ & $75.3 \mathrm{a}$ & $41.9 \mathrm{~b}$ & $79.0 \mathrm{a}$ & $78.4 \mathrm{~b}$ \\
\hline CWE 1-week interval & $55.8 \mathrm{ab}$ & $31.0 \mathrm{c}$ & $76.7 \mathrm{a}$ & $37.5 \mathrm{~b}$ & $86.8 \mathrm{a}$ & $82.3 \mathrm{ab}$ \\
\hline CWE 2-week interval & $55.0 \mathrm{ab}$ & $31.8 \mathrm{c}$ & $75.8 \mathrm{a}$ & $38.5 \mathrm{~b}$ & $85.3 \mathrm{a}$ & $81.1 \mathrm{ab}$ \\
\hline
\end{tabular}

x Twelve foliar applications of chlorothalonil (Bravo Ultrex) alone (1997; $2 \mathrm{~kg} \mathrm{ha}^{-1}$ ) or mixed with copper hydroxide (Kocide 101) (1998; 2 kg ha ${ }^{-1}$ ) and acibenzolar-S-methyl (35 $\mathrm{g}$ a.i. $\left.\mathrm{ha}^{-1}\right)$ at 7 - to 10 -day intervals. CWE were applied at weekly or biweekly intervals. Control plants were sprayed with water.

y Total ripe fruit (\%total fruit).

${ }^{\mathrm{z}}$ Means followed by the same letter in each column do not differ significantly $(P \leq 0.05$, least squares means option of the general linear models procedure of SAS).

that of Cronin et al. (11), who reported that products of anaerobic metabolism were critical to activity against Venturia inaequalis (Cooke) G. Wint. In this work, activity of extracts after filtration or autoclaving revealed that biocontrol agents possibly present in the unfiltered extracts were not essential to compost extract efficacy. The extracts used in the field, however, were not filtered or autoclaved and undoubtedly harbored significant populations of biocontrol agents because they were prepared from mature composts, which typically are colonized by a great diversity of such microorganisms $(3,5,7$, $18,20)$. Finally, extracts used in this work did not inhibit in vitro growth of $X$. vesicatoria (data not presented). Thus, although a number of factors may have contributed to efficacy, filterable, heat-stable components seemed to play a role in efficacy.

In conclusion, the data obtained in this work agree with that reported previously on the activity of compost water extracts $(11,13,23,27,33,35,36)$. This, to our knowledge, is the first report on field activity of such extracts against a bacterial disease. Even though some degree of efficacy was observed in this work against this disease, it was not comparable to the effect of a mixture of copper hydroxide and chlorothalonil. Activity of the extracts was more in line with that reported for the SAR inducer acibenzolar-S-methyl $(15,24,28)$.

\section{ACKNOWLEDGMENTS}

This research was supported by grants from the USDA North Central Sustainable Agriculture Research and Education Program and the United Arab Emirates University, Al-Ain, U.A.E., and by state and federal funds appropriated to The Ohio State University and the Ohio Agricultural Research and Development Center, Wooster. We thank L. V. Madden, OSU Department of Plant Pathology, for advice on statistical analyses, and M. E. Watson, OSU School of Natural Resources, for advice on fertility aspects of compost and soils. Technical assistance provided by Carol Musselman, Matthew Krause, Fikrettin Sahin, Lynn West, and Andrea Denning is greatly acknowledged. We also thank the following organizations: Hirzel Farms, Luckey, OH; Kurtz Brothers, Independence, $\mathrm{OH}$; and Syngenta Crop Protection, Greensboro, NC. We thank L. V. Madden and M. A. Ellis for reading this manuscript.

\section{LITERATURE CITED}

1. Abbasi, P. A., Al-Dahmani, J., Sahin, F., Hoitink, H. A. J., and Miller, S. A. 2002. Effect of compost amendments on disease severity and yield of tomato in conventional and organic production systems. Plant Dis. 86:156-161.

2. Achimu, P., and Schlösser, E. 1991. Control of Plasmopara viticola with compost filtrates. Med. Fac. Landbouww. Rijksuniv. Gent 56:171-178.

3. Alvarez, M. A., Gagné, S., and Antoun, H. 1995. Effect of compost on rhizosphere microflora of the tomato and on the incidence of plant growth-promoting rhizobacteria. Appl. Environ. Microbiol. 61:194-199.

4. Boehm, M. J., and Hoitink, H. A. J. 1992. Sustenance of microbial activity in potting mixes and its impact on severity of Pythium root rot of poinsettia. Phytopathology 82:259264.

5. Boehm, M. J., Wu, T., Stone, A. G., Kraakman, B., Iannotti, D. A., Wilson, G. E., Madden, L. V., and Hoitink, H. A. J. 1997. Crosspolarized magic-angle spinning ${ }^{13} \mathrm{C}$ nuclear magnetic resonance spectroscopic characterization of soil organic matter relative to culturable bacterial species composition and sustained biological control of Pythium root rot. Appl. Environ. Microbiol. 63:162-168.

6. Brinton, W. F., Tränker, A., and Droffner, M. 1996. Investigation into liquid compost extracts. Proc. Fla. Hortic. Soc. 105:68-70.

7. Bulluck, L. R., III, and Ristaino, J. B. 2002. Effect of synthetic and organic soil fertility amendments on southern blight, soil microbial communities, and yield of processing tomatoes. Phytopathology 92:181-189.

8. Chen, L., Dick, W. A., Streeter, J. G., and Hoitink, H. A. J. 1996. Ryegrass utilization of nutrients released from composted biosolids and cow manure. Compost Sci. Util. 4:73-83.

9. Chen, Y., and Inbar, Y. 1993. Chemical and spectroscopical analyses of organic matter transformations during composting in relation to compost maturity. Pages 551-600 in: Science and Engineering of Composting: Design, Environmental, Microbiological and Utilization Aspects. H. A. J. Hoitink and H. M. Keener, ed. Renaissance Publications, Worthington, $\mathrm{OH}$.

10. Conover, R. A., and Gerhold, N. R. 1981. 
Mixtures of copper and maneb or mancozeb for control of bacterial spot of tomato and their compatibility for control of fungus diseases. Fla. State Hortic. Soc. 94:154-156.

11. Cronin, M. J., Yohalem, D. S., Harris, R. F., and Andrews, J. H. 1996. Putative mechanism and dynamics of inhibition of the apple scab pathogen Venturia inaequalis by compost extracts. Soil Biol. Biochem. 28:1241-1249.

12. Duffy, B. K., Sarreal, C., Stevenson, R. Ravva, S., and Stanker, L. 2002. Regrowth of pathogenic bacteria in compost teas and risk of transmission to strawberry plants. Pages 1142-1149 in: Proc 2002 Int. Sympos. Composting Compost Util. F. C. Michel, Jr., R. Rynk, and H. A. J. Hoitink, eds. The JG Press, Inc., Emmaus, PA. Published online.

13. Elad, Y., and Shteinberg, D. 1994. Effect of compost water extracts on grey mold (Botrytis cinerea). Crop Prot. 13:109-114.

14. Goode, M. J., and Sasser, M. 1980. Prevention - the key to controlling bacterial spot and bacterial speck of tomato. Plant Dis. 64:831834.

15. Görlach, J., Volrath, S., Knauf-Beiter, G., Beckhove, U., Kogel, K.-H., Oostendrop, M., Staub, T., Ward, E., Kessmann, H., and Ryals, J. 1996. Benzothiadiazole, a novel class of inducers of systemic acquired resistance, activates gene expression and disease resistance in wheat. Plant Cell 8:629-643.

16. Grebus, M. E., Watson, M. E., and Hoitink, H. A. J. 1994. Biological, chemical and physical properties of composted yard trimmings as indicators of maturity and plant disease suppression. Compost Sci. Util. 2:57-71.

17. Han, D. Y., Coplin, D. L., Bauer, W. D., and Hoitink, H. A. J. 2000. A rapid bioassay for screening rhizosphere microorganisms for their ability to induce systemic resistance. Phytopathology 90:327-332.

18. Hoitink, H. A. J., and Boehm, M. J. 1999. Biocontrol within the context of soil microbial communities: A substrate-dependent phenomenon. Annu. Rev. Phytopathol. 37:427446.
19. Hoitink, H. A. J., Inbar, Y., and Boehm, M. J. 1991. Status of compost-amended potting mixes naturally suppressive to soilborne diseases of floricultural crops. Plant Dis.75:869873.

20. Hoitink, H. A. J., Stone, A. G., and Han, D. Y. 1997. Suppression of plant diseases by composts. HortScience 32:184-187.

21. Horsfall, J. G., and Barratt, R. W. 1945. An improved grading system for measuring plant diseases. (Abstr.) Phytopathology 35:655.

22. Iannotti, D. A Grebus, M. E., Toth, B. L., Madden, L. V., and Hoitink, H. A. J. 1994. Oxygen respirometry to assess stability and maturity of composted municipal solid waste. J. Environ. Qual. 23:1177-1183.

23. Jongebloed, P. H. J., Kessel, G. J. T., Molhoek, W. M. L., van der Plas, C. H., and Fokkema, N. J. 1993. Biological control of Phytophthora infestans with compost extracts and selected bacterial antagonists. Pages 16-20 in: Biological Control of Foliar and Post-Harvest Diseases: Proc. Workshop. N. J. Fokkema, J. Kohl, and Y. Elad, eds. IOBC/WPRS, Montfavet, France.

24. Lawton, K. A., Friedrich, L., Hunt, M., Weymann, K., Delaney, T., Kessmann, H., Staub, T., and Ryals, J. 1996. Benzothiadiazole induces resistance in Arabidopsis by activation of the systemic acquired resistance signal transduction pathway. Plant J. 10:71-82.

25. Lelliot, R. A., and Stead, D. E. 1987. Methods for the Diagnosis of Bacterial Diseases of Plants. Blackwell Scientific Publications, Ltd., Oxford.

26. Louws, F. J., Wilson, M., Campbell, H. L., Cuppels, D. A., Jones, J. B., Shoemaker, P. B., Sahin, F., and Miller, S. A. 2001. Field control of bacterial spot and bacterial speck of tomato using a plant activator. Plant Dis. 85:481-488.

27. McQuilken, M. P., Whipps, J. M., and Lynch, J. M. 1994. Effects of compost water extracts of a composted manure-straw mixture on the plant pathogen Botrytis cinerea. World J. Microbiol. Biotech. 10:20-26.

28. Pharand, B., Carisse, O., and Benhamou, N.
2002. Cytological aspects of compostmediated induced resistance against crown and root rot in tomato. Phytopathology 92:424-438.

29. Precheur, R. J., ed. 2000. Ohio Vegetable Production Guide. Ohio State Univ. Ext. Bull. 672.

30. Puustjarvi, V., and Robertson, R. A. 1975. Physical and chemical properties. Pages 2328 in: Peat in Horticulture. F. O. Larsen and B. G. Joyner, eds. Academic Press, Inc., New York.

31. Romero, A. M., Kousik, C. S., and Ritchie, D. F. 2001. Resistance to bacterial spot in bell pepper induced by acibenzolar-S-methyl. Plant Dis. 85:189-194.

32. Sahin, F., and Miller, S. A. 1996. Characterization of Ohio strains of Xanthomonas campestris pv. vesicatoria, causal agent of bacterial spot of pepper. Plant Dis. 80:773-778.

33. Scheuerell, S. J., and Mahaffee, W. F. 2000 Assessing aerated and non-aerated watery fermented compost and Trichoderma harzianum T-22 for control of powdery mildew (Sphaerotheca pannosa var. rosae) of rose in the Willamette Valley, Oregon. (Abstr.) Phytopathology 90:S69.

34. Sijam, K., Chang, C. J., and Gitaitis, R. D. 1991. An agar medium for the isolation and identification of Xanthomonas campestris pv. vesicatoria from seed. Phytopathology 81:831-834.

35. Weltzien, H. C. 1992. Biocontrol of foliar fungal diseases with compost extracts. Pages 430-450 in: Microbial Ecology of Leaves. J H. Andrews and S. S. Hirano, eds. SpringerVerlag, New York.

36. Yohalem, D. S., Nordheim, E. V., and Andrews, J. H. 1996. The effects of water extracts of spent mushroom compost on apple scab in the field. Phytopathology 86:914-922.

37. Zhang, W., Han, D. Y., Dick, W. A., Davis, K. R., and Hoitink, H. A. J. 1998. Compost and compost water extract-induced systemic acquired resistance in cucumber and Arabidopsis. Phytopathology 88:450-455. 